\title{
Elimination of Pollution of Groundwater by On-Site Sanitation Systems
}

\author{
Michael Kyakula, Simon Okiror, Paul Kawesa \\ Department of Civil and Building Engineering, Kyambogo University, Kampala, Uganda \\ Email:mkyakula@yahoo.com
}

Received 31 October 2015; accepted 14 December 2015; published 17 December 2015

Copyright $\odot 2015$ by authors and Scientific Research Publishing Inc.

This work is licensed under the Creative Commons Attribution International License (CC BY). http://creativecommons.org/licenses/by/4.0/

(c) (i) 0 pen Access

\begin{abstract}
About half the population in developing countries lack safe excreta disposal facilities. Improper wastewater disposal contaminates groundwater resulting in spread of water related diseases such as typhoid, cholera, dysentery. This research experimentally tested the applicability of charcoal and saw dust packed membranes as sewage purifiers for on-site sanitation systems like, septic tanks, cesspool, pit latrines, pour-flush pit excreta systems. Tests for $E$. coli, COD and BOD of the influent which was raw sewerage from sewers and effluent from layered saw dust and charcoal purifying materials experimental setup were separately carried out. The layers were varied from $150 \mathrm{~mm}, 200 \mathrm{~mm}$ and $300 \mathrm{~mm}$ with $150 \mathrm{~mm}$ layers of gravel in between. The experimental tests showed that $300 \mathrm{~mm}$ charcoal layers with a $150 \mathrm{~mm}$ gravel middle layer, reduced $E$. coli from $4800 \times 10^{14} \mathrm{CFU} / 100 \mathrm{ml}$ to $1.08 \times 10^{4} \mathrm{CFU} / 100 \mathrm{ml}$, BOD5 from $698 \mathrm{mg} / \mathrm{l}$ to $0.5 \mathrm{mg} / \mathrm{l}$, COD from 1492 $\mathrm{mg} / \mathrm{l}$ to $3.0 \mathrm{mg} / \mathrm{l}$ against environmental standards of $1.0 \times 10^{4} \mathrm{CFU} / 100 \mathrm{ml}, 50 \mathrm{mg} / \mathrm{l}$, and $100 \mathrm{mg} / \mathrm{l}$ respectively and its efficiency is directly proportional to thickness of charcoal dust layers. In conclusion, introducing a lined purification chamber with layers of charcoal dust between the onsite sanitation system and soak pit will eliminate the pollution of ground water.
\end{abstract}

\section{Keywords}

Elimination of Pollution, Groundwater, Membrane Filters

\section{Introduction}

One of the major challenges faced by the developing countries is that of human waste management and disposal. Nearly half the urban population lack adequate safe waste disposal facilities and a very insignificant portion of rural population do not have proper waste disposal facilities [1]. The sanitation practices that are promoted fall 
into one of the two broad systems: on-site and offsite sanitation systems. The onsite sanitation system is subdivided into three major types: flush and discharge, ecological (EcoSan toilets) and the traditional drop and store (pit latrine). Human faeces are dangerous to health and detrimental to the environment if not purified or untreated before being disposed into the environment. A WHO Study Group defined sanitation as "the means of collecting and disposing of excreta and community liquid wastes in a hygienic way so as not to endanger the health of individuals and the community as a whole” [2]. Hygienic disposal of human wastes that does not endanger health should be the underlying objective of all sanitation programmes [3].

\section{Pathogen Characteristics}

Human excreta contains four types of pathogens; Eggs of helminthes (worms), Protozoa, Bacteria and Viruses. Helminthes and protozoa are relatively large $(>25 \mu)$ they are removed efficiently through physical filtration in the soil and it is unlikely they will pollute groundwater. Bacteria and viruses are much smaller. The percolating effluent from sanitation systems can transport bacteria and viruses into the groundwater and these organisms may be ingested and cause infection. Faecal matter contains an average of 109 bacteria per gram, while an infected individual can excrete up to 106 viruses per gram of faeces [4]. The rate of inactivation by natural or artificial processes depends on both the efficiency of removal and the numbers initially present. The distance over which enteric bacteria are traced depends on their death rate, velocity of the groundwater, initial concentration of enteric bacteria and their dispersion within the groundwater body. The maximum linear diffusion appears to be that distance which the groundwater flows in about 10 days. Viruses are much smaller than bacteria. Removal appears to depend almost entirely on adsorption which is not an irreversible process [4].

\section{Faecal Pollution in Drinking Water}

Waterborne diseases such as cholera, typhoid, amoebic and bacillary dysentery and other diarrheal diseases are caused by the ingestion of water contaminated by human wastes or animal faeces or urine containing pathogenic bacteria. Worldwide approximately 250 million people are infected with waterborne diseases, which results in 10 to 20 million deaths annually. In Uganda about 21 million (approximately two thirds of the population) lack basic sanitation [5]. The control of these waterborne diseases is performed by monitoring the microbiological quality of underground drinking water by routine assessment [6]. The presence of coliforms such as Escherichia coli (E. coli) in water indicates faecal pollution since coliforms are present in large numbers in the intestinal flora of both humans and warm blooded animals [7].

The Uganda National Environment Management Authority (NEMA) disposal requirement of treated wastewater is a maximum limit of $1.0 \times 10^{4} \mathrm{CF} / 100 \mathrm{ml}$ E. coli (faecal coliforms), [8]. Unfortunately on-site sanitation systems receive and dispose human waste directly to the underground streams (aquifer) unpurified at $5.0-6.9 \times 10^{9} \mathrm{CF} / 100 \mathrm{ml}$ E. coli thus contaminating ground water sources; posing public health threats with water related diseases like typhoid, cholera, and dysentery. This results into high government expenditure on treatment. COD corresponds to the amount of oxygen required to chemically oxidize organic matter by a strong oxidant for example permanganate $\mathrm{Mn}_{2} \mathrm{O}^{4-}$ or dichromate $\mathrm{Cr}_{2} \mathrm{O}_{7}^{2-}$ in acid solution. BOD determines the oxygen consumption of microorganisms during biodegradation of organic matter. It is widely used parameter to quantify organic matter pollution in the waste water as it best reflects the actual process taking place in sewage treatment plants. The rate of biodegradation depends on temperature, therefore the standard BOD test is fixed at $20^{\circ} \mathrm{C}$ and the incubation period is 5 days. This is expressed as $\left(B O D 5_{20}\right)$.

\section{Methodology}

The study carried out tests on influents and effluents of experiential setups of layered charcoal and saw dust purifying materials for $E$. coli or fecal coliforms, Chemical oxygen demand [COD] and Biological oxygen demand [BOD] parameters. There are vast heaps of waste charcoal dust left over from use of charcoal as fuel and excess saw dust from carpentry workshops and saw mills in various urban centers in Uganda with no adequate recycle methods leading to environmental solid waste pollution. The research therefore investigated the efficiency and practical applicability of these materials packed membranes as sewage purifiers for on-site sanitation systems like, septic tanks, cess pool pits, pit latrines, pour-flush pit excreta systems. 


\subsection{Experimental Setup}

The apparatus was erected as shown in Figure 1; Material membranes (charcoal dust and saw dust) were picked from disposal grounds. One 18.5 liter mineral water bottle was filled with $150 \mathrm{~mm}$ well compacted layers of charcoal dust at the bottom, followed by $150 \mathrm{~mm}$ gravel, $150 \mathrm{~mm}$ charcoal dust, $50 \mathrm{~mm}$ of stone dust at the top. Then another 18.5 liter mineral water bottle was filled with $150 \mathrm{~mm}$ well compacted layers of saw dust at the bottom, followed by $150 \mathrm{~mm}$ gravel, $150 \mathrm{~mm}$ saw dust, and $50 \mathrm{~mm}$ of stone dust at the top. The sewerage influent was then poured and allowed to flow under gravity through arrangement of compacted layers. The resultant effluent water was collected in beakers ready for laboratory tests. The material membrane layers of saw dust and charcoal dust were then varied to different thicknesses of $200 \mathrm{~mm}$ and 300 in fresh set of bottles, keeping gravel at $150 \mathrm{~mm}$ thickness in each case.

\subsection{Waste Water Sampling and Field Study}

Waste water samples were collected on daily basis for three days. Central Waste Water Treatment Plant in Kampala for the National Water and Sewerage Corporation (NWSC) sampling point was selected as a source of raw sewerage. The Central Waste Water Treatment Plant was chosen because it provided an experimental room for the setup experiment; it also had well mixed and easily sampled sewage and proximity of laboratories for easy access to perform the prescribed tests within the 3 hour limit set by the national standards.

\subsection{Sample Size}

The random samples were collected; the samples were grouped into three sets. Each collected per week, preserved, analyzed at the quality control laboratory, values recorded and quantified accordingly. The sampled volumes of the pollution parameters were as in given in Table 1 .

\subsection{Determination of Characteristics}

Physical characteristics were determined by observing the colour of both the influent and effluent from the experimental setup. Chemical characteristics involved determination of BOD and COD. Micro biological characteristics aimed at determining feacal coliforms count of influent and effluent. This was used to indicate the extent of feacal pollution of waste water thus presence of enteric pathogens.

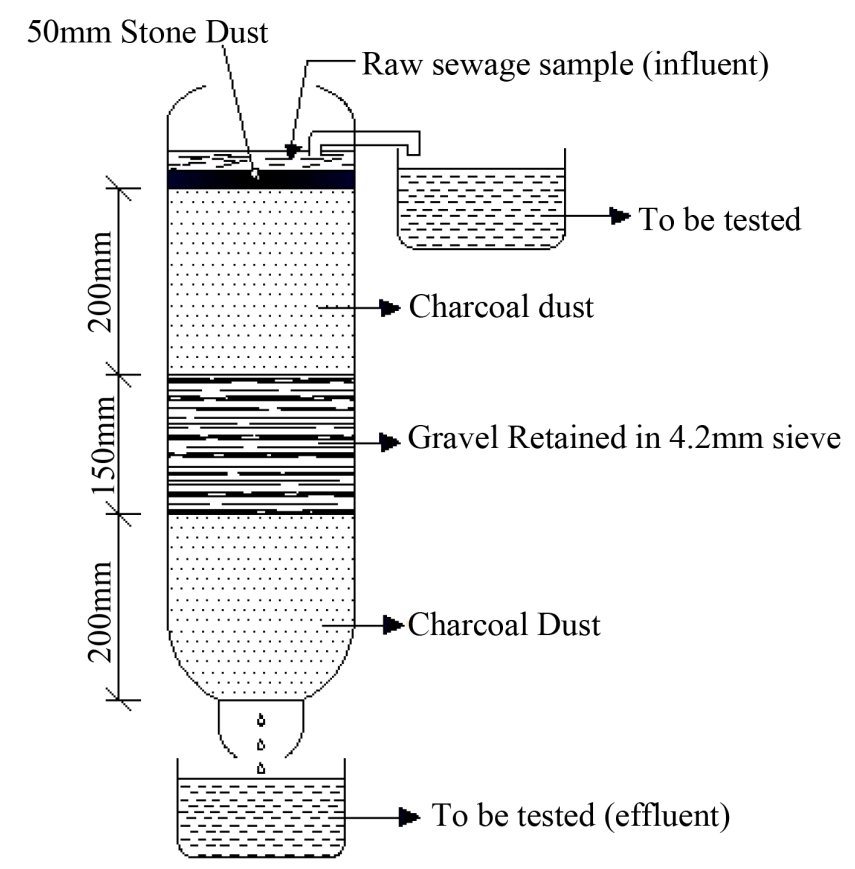

Figure 1. Experimental. 
Table 1. Sampled volumes of pollution parameters.

\begin{tabular}{cc}
\hline Pollution Parameters & Sampled Volumes (mls) \\
\hline BOD & 100 \\
COD & 50 \\
E. coli & 100 \\
\hline
\end{tabular}

\subsection{Biochemical Oxygen Demand (BOD5)}

Samples of wastewater at the inlet channel were collected using well-cleaned, thoroughly rinsed and air dried incubation bottles. Water seals were created by aspirating water into the mouth of the flair bottle and covering the mouth with an Aluminum foil paper or cup to minimize effects of evaporation in the water seal. Then, the samples were prepared to required dilutions. Determination of biochemical oxygen demand (BOD5) was done using Azide modification of wrinkle oxygen electrode method. The method involved filling an airtight bottle with a sample and incubating it at a temperature of $20^{\circ} \mathrm{C}$ for 5 days. Dissolved oxygen (DO) was measured before and after incubation and the BOD was measured as a difference of the initial and final DO.

For each test bottle meeting the $2.0-\mathrm{mg} / \mathrm{l}$ minimum DO depletion and the $1.0-\mathrm{mg} / \mathrm{L}$ residual.

DO, BOD5 was calculated as follows;

When dilution water is not seeded:

$$
\mathrm{BOD}_{5}(\mathrm{mg} / \mathrm{l})=\frac{D_{1}-D_{2}}{P}
$$

When dilution water is seeded:

$$
\mathrm{BOD}_{5}(\mathrm{mg} / \mathrm{l})=\frac{\beta_{1}-\beta_{2}}{f}
$$

where:

$D_{1}=$ DO of diluted sample immediately after preparation, $\mathrm{mg} / \mathrm{l}$,

$D_{2}=$ DO of diluted sample after $5 \mathrm{~d}$ incubation at $20^{\circ} \mathrm{C}, \mathrm{mg} / \mathrm{l}$,

$P=$ decimal volumetric fraction of sample used,

$\beta_{1}=\mathrm{DO}$ of seed control before incubation, $\mathrm{mg} / \mathrm{l}$,

$\beta_{2}=\mathrm{DO}$ of seed control after incubation $\mathrm{mg} / \mathrm{l}$, and

$f=$ ratio of seed in diluted sample to seed in seed control $=(\%$ seed in diluted sample $) /(\%$ seed in seed control).

If seed material is added directly to sample or to seed control bottles:

$f=$ (volume of seed in diluted sample)/(volume of seed in seed control).

\subsection{Chemical Oxygen Demand (COD)}

The apparatus included; digestion vessels, heating blocks or ovens to operate at $150^{\circ} \mathrm{C} \pm 2{ }^{\circ} \mathrm{C}$. Samples from specific sampling points were collected in glass bottles or clean plastic bottles as above. Determination of chemical oxygen demand (COD) was done using closed reflux calorimetric method. $50 \mathrm{ml}$ of wastewater sample, diluted was refluxed in a strongly acid solution with a known excess of Potassium dichromate solution $\left[\mathrm{K}_{2} \mathrm{Cr}_{2} \mathrm{O}_{2}\right]$. The amount of dichromate consumed is proportional to the oxygen required to oxidize the oxidizable organic matter in the sample.

\subsection{Faecal Coliforms (E. coli Colonies)}

Samples were collected in a clean, clear, sterile glass/plastic bottles with a stopper. A septic method of sampling was used to avoid sample contamination. The representative samples were preserved in a cool box containing ice to avoid alteration of the bacteriological status of the sampled wastewater. Equipment and apparatus needed were; a filtering unit, membrane filter pads, autoclave or ovens, incubator, Petri-dishes, forceps, pipettes (granulated type), digital counter, transfer pipette, water still, measuring cylinder, sterilizing banner, hot plate, disinfectant (70\% ethanol), weighing balance and thermometer. 
Determination of Faecal coliforms was done using membrane filtration method employing Laurel Sulphate broth. A measure of $100 \mathrm{ml}$ was filtered through a membrane filter composed of cellulose esters which retains all the bacteria on the surface of the membrane which was then incubated with the girded side upon a selective media. The Petri-dish was covered with the lid upper most and placed onto the carrier, then placed in the incubator. The incubator was set at $44^{\circ} \mathrm{C} \pm 0.5^{\circ} \mathrm{C}$ for 30 mins before the sample was incubated. The thermometer was placed in the incubator to cross check the temperature, then the sample incubated for 24 hours. After incubation the carriers were removed and Petri-dishes allowed cool for 10 mins to allow a false yellow colour to lose and ensure that the yellow was only for the typical E. coli colonies. A low power microscope (10 - 15× magnification lens) and a counting pen were used to count the colonies. All the yellow, pale yellow colonies which are convex, dome-shaped colonies with a reflective surface were counted as true colonies which may be feacal coliform or suspect $E$. coli but if not incubated at $35^{\circ} \mathrm{C}$ then it was considered to be total coliform. The suspended $E$. coli was confirmed using both brilliant green broth and Tryptone water.

To compute E. coli density, the following empirical formulae were used. Equation (3) was applied for coliform density on a single membrane filter.

$$
\text { Coliform colonies }=\frac{\text { coliforms counted }}{\text { Actual volume }(\text { in ml }) \text { filtered }} \times 100 \mathrm{CF} / 100 \mathrm{ml}
$$

Equation (4) is applied for average coliform density, if no filter meets the desired minimum colony count. The equation is suited 1) duplicates; 2) Multiple dilutions, or more than one filter/sample.

$$
\text { Coliform colonies }=\frac{\text { sum of colonies in all samples }}{\text { sum of volume }(\text { in } \mathrm{ml}) \text { of all samples }} \times 100 \mathrm{CFU} / 100 \mathrm{ml}
$$

For total solid (dry weight basis), the feacal coliforms per gram dry weight for bio solid analysis was calculated as shown in Equation (5)

$$
\text { Coliform coliforms gram per } 100 \mathrm{ml}=\frac{\text { colonies counted }}{(\text { Dilution chosen }) \times(\% \text { dry solids })} \times 100
$$

Data collected was analyzed using empirical formulae above. The results were compared with the NEMA effluent standards (maximum permissible limits) for discharge of waste water in Uganda. After analysis of the results, the discussions included design of an appropriate technology to exploit the result of the experiment.

\section{Results}

From Table 2, it is seen that the initial flow through charcoal dust is fast and it slows down as the charcoal absorbs water, on the other hand the initial flow in saw dust is low because the saw dust is absorbing the water, after it is saturated with water the flow increases. Charcoal dust is very good in removing colour and suspended solids, whereas saw dust is not good.

From Table 3, the raw sewage samples collected at the inlet of disposal unit gave an average value of $58000 \times 10^{4}$ bacterial colonies by density. After filtration treatment/purification on a layers of $(150 \mathrm{~mm}, 150$ $\mathrm{mm}, 150 \mathrm{~mm}$ ) of (charcoal, gravel, charcoal) and (sawdust, gravel, sawdust), the microbial load of bacteria reduced to $13.6 \times 10^{4}$, a reduction factor of 4265 for charcoal and $320 \times 10^{4}$, a reduction factor of only 181 for saw dust. Despite these high reduction rates, the values obtained are still' high above the discharge limit of $1.0 \times 10^{4} / 100 \mathrm{ml}$ for waste water by National Environment Management Authority (NEMA).

From Table 4, the average contamination density of raw sewage sample is $43000 \times 10^{4} / 100 \mathrm{ml}$ feacal coliforms (E. coli). Effluent from charcoal and saw dust gave $7.8 \times 10^{4} / 100 \mathrm{ml}$ and $296 \times 10^{4} / 100 \mathrm{ml}$ fecal coliforms (E. coli) densities giving reduction factors of 5513 and 145 respectively. The purification layers were 200 $\mathrm{mm}$ each and gravel kept at $150 \mathrm{~mm}$ thickness. This set shows a remarkable improvement in purification of microbial bacteria. But still fecal colonies are slightly above upper recommended discharge limit of $1.0 \times 10^{4} / 100 \mathrm{ml}$.

BOD5 reduced from $647.6 \mathrm{mg} / \mathrm{l}$ in the influent to $2 \mathrm{mg} / \mathrm{l}$ and $438.5 \mathrm{mg} / \mathrm{l}$ for charcoal and saw dust respectively against environmental standards of $50 \mathrm{mg} / \mathrm{l}$. COD reduced from $1345 \mathrm{mg} / \mathrm{l}$ in the influent to $7.6 \mathrm{mg} / \mathrm{l}$ and $967 \mathrm{mg} / \mathrm{l}$ for charcoal and saw dust respectively against environmental standards of $100 \mathrm{mg} / \mathrm{l}$.

From Table 5 for purification layers of $300 \mathrm{~mm}$ each and keeping gravel thickness at $150 \mathrm{~mm}$. $1.08 \times 10^{4}$ / $100 \mathrm{ml}$ and $128 \times 10^{4} / 100 \mathrm{ml}$ fecal coliforms (E. coli) by densities were realized from a raw average sewage 
Table 2. Observed results from the experimental setup.

\begin{tabular}{|c|c|c|c|c|}
\hline \multirow{2}{*}{$\begin{array}{c}\text { Filter } \\
\text { Membrane }\end{array}$} & \multicolumn{2}{|c|}{ Rate of Flow (Filtration) } & \multirow{2}{*}{ Colour of Effluent } & \multirow{2}{*}{ Suspended Solids } \\
\hline & Initial & Final & & \\
\hline Charcoal Dust & Fast & Low & Clear Water & Nil \\
\hline Saw Dust & Low & Fast & Brownish water & Available \\
\hline
\end{tabular}

Table 3. Table of analytical results (150 mm membrane).

\begin{tabular}{cccccc}
\hline Parameters & Units & Influent & \multicolumn{2}{c}{ Effluents } & Environmental \\
\cline { 5 - 6 } & & & Charcoal & Saw Dust & Standards \\
\hline Waste Water Sample Number & - & K1518/13 & K1519/13 & K1520/13 & \\
Faecal Coliforms & CFU/100ml & $58000 \times 10^{4}$ & $13.6 \times 10^{4}$ & $320 \times 10^{4}$ & $1.0 \times 10^{4}$ \\
\hline
\end{tabular}

Table 4. Table of analytical results (200 mm membranes).

\begin{tabular}{cccccc}
\hline \multirow{2}{*}{ Parameters } & Units & Influent & \multicolumn{2}{c}{ Effluents } & Environmental \\
\cline { 5 - 6 } & & & Charcoal & Saw Dust & Standards \\
\hline Waste Water Sample Number & - & K1521/13 & K1522/13 & K1523/13 \\
Faecal Coliforms & CFU/100ml & $43000 \times 10^{4}$ & $7.8 \times 10^{4}$ & $296 \times 10^{4}$ & $1.0 \times 10^{4}$ \\
BOD5 & $\mathrm{mg} / \mathrm{l}$ & 647.6 & 2 & 438.5 & 50 \\
COD & $\mathrm{mg} / \mathrm{l}$ & 1345 & 7.6 & 967 & 100 \\
\hline
\end{tabular}

Table 5. Table of analytical results (300 mm membranes).

\begin{tabular}{|c|c|c|c|c|c|}
\hline \multirow{2}{*}{ Parameters } & \multirow{2}{*}{ Units } & \multirow{2}{*}{ Influent } & \multicolumn{2}{|c|}{ Effluents } & \multirow{2}{*}{$\begin{array}{l}\text { Environmental } \\
\text { Standards }\end{array}$} \\
\hline & & & Charcoal & Saw Dust & \\
\hline Waste Water Sample Number & - & $\mathrm{K} 1518 / 13$ & K1519/13 & K1520/13 & \\
\hline Faecal Coliforms & CFU/100ml & $48000 \times 10^{4}$ & $1.08 \times 10^{4}$ & $128 \times 10^{4}$ & $1.0 \times 10^{4}$ \\
\hline BOD5 & $\mathrm{mg} / \mathrm{l}$ & 698 & 0.5 & 42 & 50 \\
\hline COD & $\mathrm{mg} / \mathrm{l}$ & 1492 & 3.0 & 115 & 100 \\
\hline
\end{tabular}

density of $48000 \times 10^{4} / 100 \mathrm{ml}$ giving reduction factors of 44,444 and 375 for charcoal and saw dust respectively. This set shows a remarkable improvement in purification of microbial bacteria with fecal colonies within the upper recommended discharge limit of $1.0 \times 10^{4} / 100 \mathrm{ml}$ for the case of charcoal dust material.

BOD5 reduced from $698 \mathrm{mg} / \mathrm{l}$ in the influent to $0.5 \mathrm{mg} / \mathrm{l}$ and $42 \mathrm{mg} / \mathrm{l}$ for charcoal and saw dust respectively against environmental standards of $50 \mathrm{mg} / \mathrm{l}$. COD reduced from $1492 \mathrm{mg} / \mathrm{l}$ in the influent to $3.0 \mathrm{mg} / \mathrm{l}$ and 115 $\mathrm{mg} / \mathrm{l}$ in effluent for charcoal and saw dust respectively against environmental standards of $100 \mathrm{mg} / \mathrm{l}$.

\section{Discussions}

The saw dust effluent is not safe to be discharged into water bodies. This would be harmful to aquatic life, because all the oxidation oxygen required for their respiration would instead be used for decomposition of the organic wastes. The COD and BOD from charcoal dust filters in Table 4 and Table 5, were lower than the environmental standards. If discharged into water, it will contain less oxygen debts and can sustain aquatic life.

From Table 4 and Table 5, it is seen that charcoal dust has high efficiencies of $99.44 \%$ and 99 corresponding test values of $7.6 \mathrm{mg} / \mathrm{l}$ and $2.0 \mathrm{mg} / \mathrm{l}$ in reducing COD of effluent compared to $28.37 \%$ and $32.25 \%$; corresponding to test values of $439 \mathrm{mg} / \mathrm{l}$ and $967 \mathrm{mg} / \mathrm{l}$ for saw dust. Also charcoal dust has equally high efficiencies of $99.44 \%$ and $99 \%$ corresponding to test values of $3.0 \mathrm{mg} / \mathrm{l}$ and $0.5 \mathrm{mg} / \mathrm{l}$ in reducing BOD of effluent compared to 
67\% and 93.93\%; corresponding to test values of 115 and 42 for saw dust. The test values for charcoal dust are below tolerance limits of 100 and $50 \mathrm{mg} / \mathrm{l}$ for COD and BOD for safe discharge to the environment. Charcoal dust as sewage purifier is more efficient or better than saw dust. This is because charcoal dust contains carbon which is riddled with small low volume pores that increase the surface area available for adsorption or chemical reactions/filtration. While, sawdust has starch and other additives that are easily oxidized or broken down to un wanted products in solution.

The efficiency of coliform reduction increases with increasing depth of the charcoal membrane filter as can be seen in Tables 3-5. For greater than $300 \mathrm{~mm}$ membrane, the effluent can be discharged to the environment without much threat to stream water and can be suited for recreation and farm irrigation. For ground water resource the technology gives preliminary treatment which when coupled with soil beneath; the resultant water is effectively purified fit for drinking.

\section{Application of Charcoal Filters for Elimination of Groundwater Pollution}

Normally waste water from a septic tank is discharged directly into the ground via a soak pit. It is proposed that a lined purification chamber be introduced between the septic tank or cesspool and the soak pit as illustrated in Figure 2 below.

\section{Conclusions}

- The experimental tests showed that fecal coliforms (E. coli) are removed by $300 \mathrm{~mm}$ thick Charcoal dust filtering media to values slightly above standard discharge limits and its efficiency is directly proportional to the thicknesses of the charcoal dust layers.

- Charcoal dust as a sewage purifier is better than saw dust; because; it is efficient in reducing BOD and COD contents to considerably very low values satisfying environmental standards and $300 \mathrm{~mm}$ thick layer has very high average efficiency of 99.98\% elimination level for fecal coliforms in the waste water.

- Introducing a lined purification chamber with layers of charcoal dust between the septic tank or cesspool and the soak pit will eliminate the pollution of ground water.

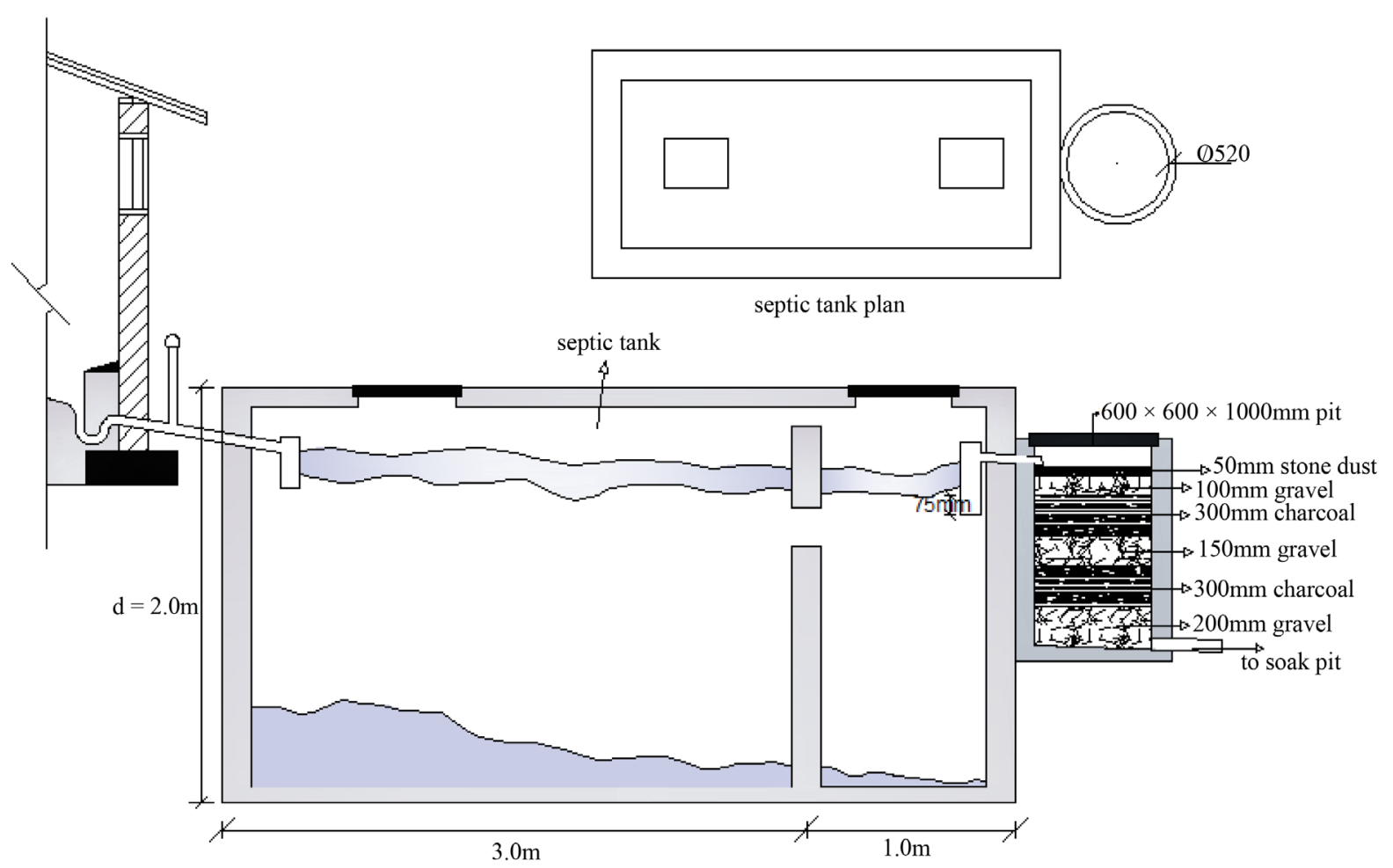

Figure 2. Application of charcoal filters in purifying sewage. 


\section{Limitation of the Research}

- It was not possible to use septic tank influent because the tests needed to be carried out near the National Water and Sewerage Corporation Laboratory. However raw sewage from sewers which was used has a higher count of pathogens than effluents of the septic tank. Further research is recommended using effluents of septic tanks and increasing the filters until the effluent is satisfies environmental standards.

- It was noted that the flow in charcoal media is fast at the beginning and reduces with time. There is need to investigate the effect on efficiency of fast soaking the charcoal in water.

\section{Acknowledgements}

The management of National Water and Sewerage Corporation; Central Laboratory Bugolobi, P. O. Box 7053, Kampala, for availing their laboratory for the student to conduct the required tests. The Belgian Technical Cooperation for funding this study [9] of which this research is part.

\section{References}

[1] World Health Organization (WHO) (1996) Guidelines for Drinking Water Quality. 2nd Edition, Health and Supporting Criteria, Vol. 2, Geneva.

[2] World Health Organization (WHO) (1987) Technology for Water Supply and Sanitation in Developing Countries. Geneva.

[3] Franceys, R., Pickford, J. and Reed, R. (1992) A Guide to Development of Onsite Sanitation. World Health Organization, Geneva.

[4] Lewis, J.W., Foster, S.D. and Draser, B.S. (1980) The Risk of Groundwater Pollution by On-Site Sanitation in Developing Countries, a Literature Review. International Reference Centre for Wastes Disposal (IRCWD) Report No. 01/82, Duebendorf.

[5] DWAF (1996) South African Water Quality Guidelines. 2nd Edition, Volume 7: Aquatic Ecosystems. Department of Water Affairs and Forestry, Pretoria.

[6] Tsai, Y.-L., Sobsey, M.D., Sangermano, L.R. and Palmer, C.J. (1993) Simple Method of Concentrating Enteroviruses and Hepatitis A Virus from Sewage and Ocean Water for Rapid Detection by Reverse Transcriptase-Polymerase Chain Reaction. Applied and Environmental Microbiology, 59, 3488-3491.

[7] Rompré, A., Servais, P., Baudart, J., de-Roubin, M. and Laurent, P. (2002) Detection and Enumeration of Coliforms in Drinking Water: Current Methods and Emerging Approaches. Journal of Microbiological Methods, 49, 31-54.

[8] The National Environment Regulations (Uganda) (1999) Standards for Discharge of Effluent into Water or Wetland. Statutory Instrument Supplement No. 5.

[9] Simon, O. (2013) Assessing Charcoal Dust and Saw Dust as Sewage Purifiers. Final Year Research Project for Bachelor of Engineering in Civil and Building Engineering, Kyambogo University, Kampala. 